\title{
Using a Participatory Learning and Action Approach to Improve Young Papuans and Moluccans' Knowledge of Herbal Drinks to Increase Immunity During the COVID-19 Pandemic
}

\author{
Rully Adi Nugroho, Sri Kasmiyati, Elizabeth Betty Elok Kristiani, Vincentia Irene \\ Meitiniarti, Agna Sulis Krave \\ Faculty of Biology, Satya Wacana Wacana Christian University \\ E-mail: kas@uksw.edu
}

\section{Article History:}

Received: July, $2^{\text {th }}, 2021$

Revised: August, 30th 2021

Accepted: Nov, 30th, 2021

Keywords: coronavirus disease, immunity booster, medicinal plants, prevention, participatory learning and action
Abstract: The introduction of coronavirus disease (COVID-19) into the human population represents a tremendous medical and economical crisis. The immune system plays a central role in protecting against this novel virus. This activity aimed to empower young generation of Papua and Maluku who lived in Salatiga Central Java using participatory learning and action approach to improve their knowledge about medicinal plants that grow in Indonesia and whose antiinflammatory, antioxidant, immunomodulatory, and antiviral properties. It was found that most of the participants (94-98\%) knew about medicinal plants. This activity also recorded a total of 35 medicinal plant species. Moreover, organoleptic test results showed that Kunyit Asam (consisted of turmeric and ginger) and Tealang (consisted of butterfly pea and lemongrass) were highly favored by panelists. Our results provide valuable information on the medicinal plants used as an immunity booster within the studied community.

\section{Introduction}

In early 2020, there was a new public health crises threatening the world with the emergence and spead of a new type of coronavirus (2019-nCoV) or severe acute respiratory syndrome coronavirus 2 (SARS-CoV-2). ${ }^{1}$ This COVID-19 has affected many people, not only in China but spreading to almost all countries and teritories in a short time including Indonesia and caused death. ${ }^{2}$

\footnotetext{
${ }^{1}$ Wang, Chen, Peter W. Horby, Frederick G. Hayden, and George F. Gao. "A Novel Coronavirus Outbreak of Global Health Concern." Lancet 395, no. 10223 (February 15 ,2020): 470-473.

${ }^{2}$ World Health Organization. "Indonesia: WHO Coronavirus Disease (COVID-19) Dashboard." https://covid19.who.int/region/searo/country/id. Diakses 22 Juni 2021.
} 
The virus itself, the environment, and the host can contribute to such disease heterogeneity. ${ }^{3}$ Although there is evidence that environmental factors have an impact on overall disease burden for society, ${ }^{4}$ the host itself seems to be the major factor explaining disease severity, infection rates, and long-term medical consequences. ${ }^{5}$ Some people who develop severe disease seem to have a suboptimal immune response initially, which might allow uncontrolled viral replication. ${ }^{6}$ Disease severity and mortality rates are significantly higher in eldery populations pointing toward lack of widespread longlasting pre-existing adaptive immunity by T or B cells against SARS-CoV-2. ${ }^{7}$ It is possible that cross-protection via adaptive immune responses against endemic coronaviruses might bein part responsible for mild disease courses in younger individuals. ${ }^{8}$ An effective immune response against SARS-CoV-2 requires both arms of the immune system, the innate immune system including granulocytes, monocytes, and macrophages among other cells of the innate immune system and the adaptive immune system with $\mathrm{T}$ and $\mathrm{B}$ cells for adaptive immunity against SARS-CoV-2. ${ }^{9}$

Because there is no registered treatment or vaccine against COVID-19. ${ }^{10}$ The immune system is the best defence because it supports the body's natural ability to defend against pathogens and resists infections. ${ }^{11}$ Until there is a vaccine, all countries issue the same recommendations as follows: compliance with sanitary and hygienic standards, limited contacts up to complete self-isolation, strengthening of body's defence

\footnotetext{
${ }^{3}$ Morens, David M, and Anthony S. Fauci. "Emerging Pandemic Diseases: How We Got to COVID-19." Cell 182, no. 5, (September 3, 2020): 1077-1092.

${ }^{4}$ Han, Emeline, Melisa Mei Jin Tan, Eva Turk, Devi Sridhar, Gabriel M Leung, Kenji Shibuya, Nima Asgari, Juhwan Oh, Alberto L. García-Basteiro, Johanna Hanefeld, et al. "Lessons Learnt from Easing COVID-19 Restrictions: An Analysis of Countries and Regions in Asia Pacific and Europe." The Lancet 396, no. 10261 (November 7-13, 2020): 1525-1534.

${ }^{5}$ Merad, Miriam, and Jerome C. Martin. "Pathological Inflammation in Patients with COVID-19: A Key Role for Monocytes and Macrophages." Nature Reviews Immunology 20, (May 6, 2020): 355-362; Vabret, Nicolas, Graham J. Britton, Conor Gruber, Samarth Hegde, Joel Kim, Maria Kuksin, Rachel Levantovsky, Louise Malle, Alvaro Moreira, Matthew D. Park, et al. "Immunology of COVID-19: Current State of the Science." Immunity 52, no. 6 (June 16, 2020): 910-941; Marchall, Michael. "The Lasting Misery of Coronavirus Long-Haulers" Nature 585, (September 14, 2020): 339-341.

${ }^{6}$ Long, Quan-Xin, Xiao-Jun Tang, Qiu-Lin Shi, Hai-Jun Deng, Jun Yuan, Jie-Li Hu, Wei Xu, Yong Zhang, FaJin Lv, Kun Su, et al. "Clinical and Immunological Assessment of Asymptomatic SARS-CoV-2 Infections" Nature Medicine 26, no. 8 (June 18, 2020): 1200-1204.

${ }^{7}$ Morens, David M, and Anthony S. Fauci. "Emerging Pandemic Diseases: How We Got to COVID-19." Cell 182, no. 5, (September 3, 2020): 1077-1092.

${ }^{8}$ Lipsitch, Marc, Yonatan H. Grad, Allesandro Sette, and Shane Crotty. "Cross-Reactive Memory T Cells and Herd Immunity to SARS-CoV-2." Nature Reviews Immunology 20 (October 6, 2020): 709-713.

${ }^{9}$ Sette, Alessandro, and Shane Crotty. "Adaptive Immunity to SARS-CoV-2 and COVID-19." Cell 184 (February 18, 2021): 861-880.

${ }^{10}$ Zhang, Lei, and Yunhui Liu. "Potential Interventions for Novel Coronavirus in China: A Systematic Review." Journal of Medical Virology 92, no. 5 (February 13, 2020): 479-490; Kumrungsee, Thanutchaporn, Peipei Zhang, Maesaya Chartkul, Noriyuki Yanaka, and Norihisa Kato. "Potential Role of Vitamin B6 in Ameliorating the Severity of COVID-19 and Its Complications." Frontiers in Nutrition 7, (October 29, 2020): 562051.

${ }^{11}$ Schultze, Joachim, and Anna C. Aschenbrenner. "COVID-19 and The Human Innate Immune System." Cell 184, no 7. (April 1, 2021): 1671-1692.
} 
systems that will both protect and lead to recovery in the event of infection. ${ }^{12}$

Herbs are traditionally used in many therapeutic practices, if not as the main, then as the accompanying therapy in combination with medications, aimed at boosting immunity for prevention. ${ }^{13}$ Phytotherapy has repeatedly proven its effectiveness, including its ability to cope with infectious diseases. ${ }^{14}$ There are medicinal plants whose extracts have an inhibitory effect on viruses such as herpes simplex virus type 2, HIV, hepatitis B virus (HBV), smallpox virus and severe acute respiratory syndrome, as well as on viral strains resistant to conventional antivirus drugs. ${ }^{15}$ Traditional herbal medicine has been practised for many centuries in the Indonesian community to maintain good health and to treat diseases. ${ }^{16}$ Much of this knowledge, however, was not recorded and was verbally passed from generation to generation, whic is common in tribes living in remote areas. ${ }^{17}$

Papua and Maluku have vast areas of land and many tribes that usually rely on medicinal plants for their health care. ${ }^{18}$ However, information about how widely knowledge on medicinal plants is disseminated is still very little. Previous study showed the importance of good documentation of medicinal plants diversity in Papua Islands. ${ }^{19}$ Another study showed that documentation of traditional knowledge on medicinal plants used by local population of North Maluku was limited. ${ }^{20}$ In order to conserve the indigenous knowledge and to pevent the extinction of their medicinal plants resources, empowering young Papuans and Moluccans to utilize medicinal plants for strengthening

\footnotetext{
${ }^{12}$ World Health Organization. "Coronavirus disease (COVID-19) Advice for the Public." https://www.who.int/emergencies/diseases/novel-coronavirus-2019/advice-for-public. Diakses 22 Juni 2021.

${ }^{13}$ Babich, Olga, Stanislav Sukhikh, Alexander Prosekov, Lyudmila Asyakina, and Svetlana Ivanova. "Medicinal Plants to Strengthen Immunity during a Pandemic." Pharmaceuticals 13, no. 10 (October 15, 2020): 313.

${ }^{14}$ Zhang, Deng-Hai, Kun-Lun Wu, Xue Zhang, Sheng-Qiong Deng, and Bin Peng. "In Silico Screening of Chinese Herbal Medicines with the Potential to Directly Inhibit 2019 Novel Coronavirus." Journal of Integrative Medicine 18, no. 2 (March, 2020): 152-158.

${ }^{15}$ Mukhtar, Muhammad, Mohammad Arshad, Mahmood Ahmad, Roger J. Pemerantz, Brian Wigdahl, and Zahida Parveen. "Antiviral Potentials of Medicinal Plants." Virus Research 131, no. 2 (February, 2008): 111-120.

${ }^{16}$ Elfahmi, Herman J. Woerdenbag, and Oliver Kayser. "Jamu: Indonesian Traditional Herbal Medicine Towards Rational Phytopharmacological Use." Journal of Herbal Medicine 4, no. 2 (June, 2014): 51-73.

${ }^{17}$ Cotton, Catherine M. Ethnobotany: Principles and Applications. Chichester, England: John Wiley, 1996.

${ }^{18}$ Lense, Obed. "The Wild Plants Ese as Traditional Medicines by Indigenous People of Manokwari, West Papua." Biodiversitas 13, no. 2 (April, 2012): 98-106; Batiha, Gaber El-Saber, Luay M. Alkazmi, Lamiaa G. Wasef, Amany Magdy Beshbishy, Eman H. Nadwa, and Eman K. Rashwan. "Syzygium aromaticum L. (Myrtaceae): Traditional Uses, Bioactive Chemical Constituents, Pharmacological and Toxicological Activities." Biomolecules 10, no. 2 (February, 2020): 202.

${ }^{19}$ Widiyastuti, Yuli, dan Tri Widayat. "Inventarisasi Tanaman Obat di Kabupaten Jayapura Propinsi Papua." Jurnal Tumbuhan Obat Indonesia 6, no. 2 (Desember, 2013): 116-126; Budiarti, Merry, Anshary Maruzy, Rohmat Mujahid, Aniska Novita Sari, Wahyo Jokopriyambodo, Tri Widayat, and Slamet Wahyono. "The use of antimalarial plants as traditional treatment in Papua Island, Indonesia." Heliyon 6, no. 12 (December, 2020): e05562.

${ }^{20}$ Susiarti, Siti, Mulyati Rahayu, dan Mohammad Fathi Royyani. "Pengetahuan dan Pemanfaatan Tumbuhan Obat Masyarakat Tobelo Dalam di Maluku Utara." Media Litbangkes 25, no. 4(Desember, 2015): 211-218.
} 
immunity during the COVID-19 pandemic is required. The aim of this community service activity was to improve young Papuans and Moluccans' knowledge on medicinal plants that grow in Indonesia and have been reported to have antioxidant, antiviral, antiinflammatory and immunomodulatory characteristics using participatory learning and action approach. This activity is expected to motivate assisted community members understand the importance of medicinal plants to strengthen the immune system to fight against COVID-19.

\section{Method}

This community service activity was held in Salatiga, Central Java for three months using participatory learning and action approach and involving young Papuans and Moluccans living in Salatiga as assisted communities. Based on the participation category, ${ }^{21}$ this community service activity consisted of 4 stages namely passive participation, participation in information giving, participation by consultation, and functional participation (Figure 1).
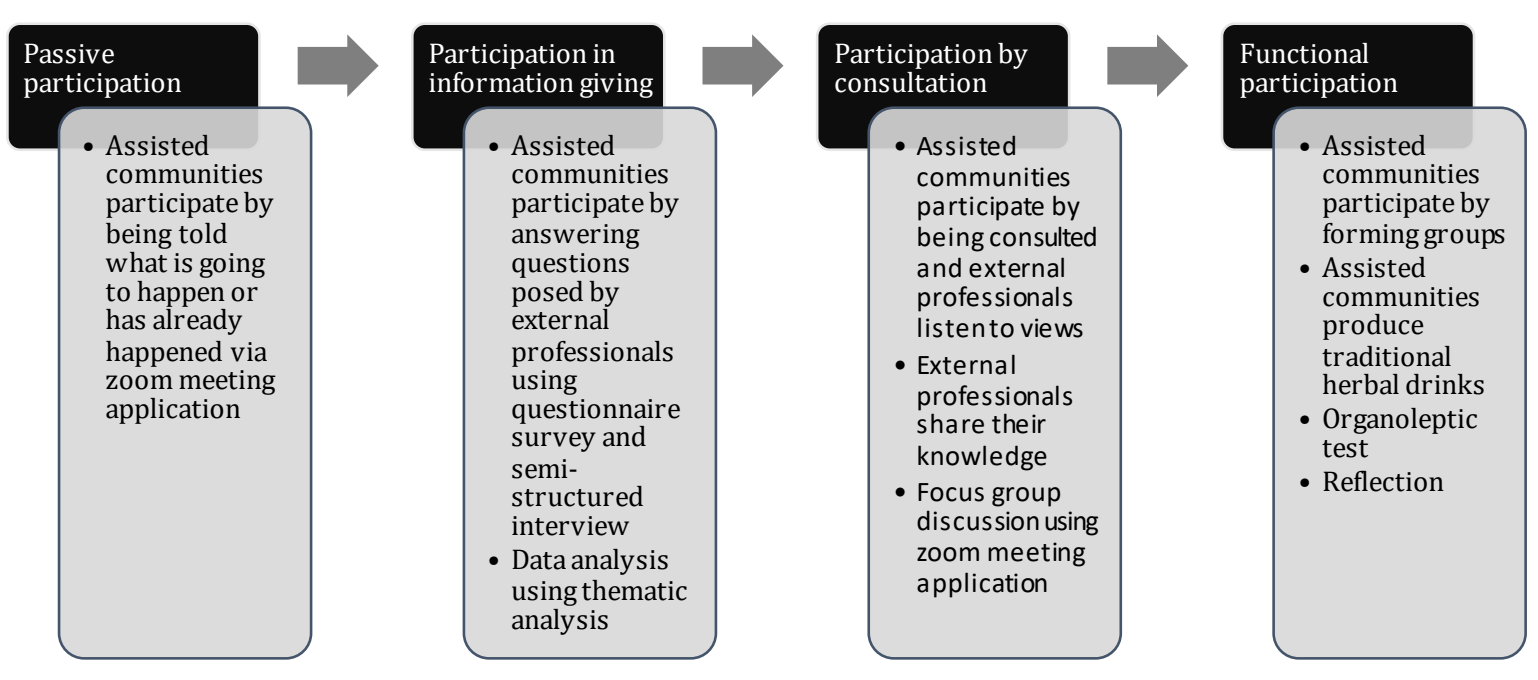

Figure 1. Flowchart of participation stage and their activities.

The passive participation stage was intended to provide information to the assisted communities. Assisted communities participated by being informed by the external professionals about the activities to be carried out, namely the use of medicinal plants, without any hearing to assisted communities' responses. The information being shared belongs only to external professionals. Information about the use of medicinal plants was given though zoom meeting application.

The second stage was intended to explore the initial knowledge of the assisted communities about medicinal plants, traditonal herbal medicines, and their uses. In this

\footnotetext{
${ }^{21}$ Pretty, Jules N, Irene Guijt, Ian Scoones, and John Thompson. Participatory Learning \& Action: A Trainer's Guide. London: International Institute for Environment and Development, 1995.
} 
stage, the assisted communities participated by answering questions from the external professionals using questionnaire survey. In addition, data were also obtained by conducting semi-structured interviews directly with the assisted communities. The data obtained through interviews were then collected and analyzed using a thematic analysis.

The third stage was intended to listen to the views of the assisted communities on the issue of knowledge and use of medicinal plants and traditional herbal medicines through focus group discussion (FGD) forums. This FGD also used zoom meeting media. Prior to the focus group discussions, the assisted communities receieved additional knowledge from the external professionals about medicinal plants species and traditional herbal medicines, as well as the importance of digitizing local knowledge.

In the fourth stage, the assisted communities formed groups to accomplished the activity goal namely making nutritious herbal drinks that can boost the immunity. These groups were still dependent on external professionals. In this functional participation stage, the assisted communities formed 8 groups.

To measure the acceptability of products from the assisted communities, an organoleptic test of herbal drink products was conducted by involving 10 consumers aged 16-43 years old. The parameters observed were appearance, taste, color, flavor, and texture using a 1-4 Likert scale. In addition, consumers also assessed the level of product innovation using a 1-4 Likert scale. At the of of the activity, reflection was also carried out to measure changes in knowledge and awareness of the assisted communities in utilizing medicinal plants using a questionnaire.

\section{Results}

This participatory learning and action activity in community service consisted of four stages. In the first stage namely passive participation, there were 163 young Papuans and Moluccans who were willing to become assisted communities in this activity. The assisted communities consisted of 70 men and 93 women with a distribution of 27 men and 22 women from Papuan ethnicity, and 43 men and 71 women from from Maluku ethnicity. Overall, the members of these assisted communities were between the ages of 20 to 30 .

In the second stage namely participation in information giving, from all young Papuans as part of the assisted communities, 46 person (95\%) answered that they less know or knew well and 3 person $(6 \%)$ answered that they did not know about medicinal plants, while from all young Moluccans, 112 person (98\%) answered that they less know or knew well and 2 person (2\%) answered that they did not know about medicinal plants. The majority of respondents who knew medicinal plants got knowledge on these plants from their families, i.e. $85 \%$ and $80 \%$ for young Papuans and Moluccans, respectively. In addition, they also got this knowledge from experiences, neighbors/ friends, and the media. 
Table 1. Medicinal plant species recognized by respondents from young Papuan and Moluccan communities

\begin{tabular}{|c|c|}
\hline Papuan ethnic group & Moluccan ethnic group \\
\hline Areca (Areca catechu) & Aromatic ginger (Kaempferia galangal) \\
\hline Ant plant (Myrmecodia spp.) & Basil (Ocimum basilicum) \\
\hline Banana (Musa paradisiaca) & Bettel pepper (Piper betel) \\
\hline Bettel pepper (Piper betel) & Bitterweed (Andrographis paniculata) \\
\hline Bitter-mellon (Momordicae charantia) & Butterfly pea (Clitoria ternatea) \\
\hline Bitterweed (Andrographis paniculata) & $\begin{array}{l}\text { Cinnamon bark (Cinnamomum } \\
\text { burmannii) }\end{array}$ \\
\hline Blackboard tree (Alstonia scholaris) & Citronella grass (Cymbopogon rardus) \\
\hline $\begin{array}{l}\text { Black-honey shrub } \\
\text { (Phyllanthus reticulatus) }\end{array}$ & Cogon grass (Imperata cylindrica) \\
\hline $\begin{array}{l}\text { Broad-leaved paperbark } \\
\text { (Melaleuca viridifolia) }\end{array}$ & Common fig (Ficus carica) \\
\hline Citronella grass (Cymbopogon nardus) & Common guava (Psidium guajava) \\
\hline Cogon grass (Imperata cylindrica) & Drumstick tree (Moringa oleifera) \\
\hline Common guava (Psidium guajava) & Garlic (Allium sativum) \\
\hline Drumstick tree (Moringa oleifera) & Ginger (Zingiber officinale) \\
\hline Edible hibiscus (Abelmoschus manihot) & Guduchi (Tinospora cordifolia) \\
\hline Ginger (Zingiber officinale) & Indian mulberry (Morinda citrifolia) \\
\hline Glorybower (Clerodendrum japonicum) & Javanese ginger (Curcuma xanthorrhiza) \\
\hline Highland pandanus (Pandanus julianettii) & Lime (Citrus aurantifolia) \\
\hline Indian mulberry (Morinda citrifolia) & $\begin{array}{l}\text { Liniment tree } \\
\text { (Asteromyrtus symphyocarpa) }\end{array}$ \\
\hline Lime (Citrus aurantifolia) & Mango ginger (Curcuma mangga) \\
\hline $\begin{array}{l}\text { Liniment tree } \\
\text { (Asteromyrtus sumphyocarpa) }\end{array}$ & Mulberry (Morus alba) \\
\hline Merremia (Ipomoea peltata) & Native gooseberry (Physalis sp.) \\
\hline Palm (Sararanga sinuosa) & Neem (Azadirachta indica) \\
\hline Papaya (Carica papaya) & Periwinkle (Catharanthus roseus) \\
\hline Red fruit (Pandanus conoideus) & Roselle (Hibiscus sabdariffa) \\
\hline Roselle (Hibiscus sabdariffa) & Sappan wood (Caesalpinia sappan) \\
\hline Rotan sega (Calamus caesius) & Shoeblackplant (Hibiscus rosa-sinensis) \\
\hline Sago palm (Metroxylon sagu) & Spadeleaf (Centella asiatica) \\
\hline Shoeblackplant (Hibiscus-rosa sinensis) & Stonebreaker (Phyllanthus ninuri) \\
\hline Soursop (Annona muricata) & True aloe (Aloe vera) \\
\hline Spadeleaf (Centella asiatica) & Turmeric (Curcuma longa) \\
\hline Sugar cane (Saccharum officinarum) & \\
\hline Sweet potato (Ipomoea batatas) & \\
\hline Thorn apple (Datura stramonium) & \\
\hline Turmeric (Curcuma longa) & \\
\hline Wild mango (Mangifera minor Blume var. & \\
\hline Biak) & \\
\hline
\end{tabular}


Based on the answers to the questionnaire and the results of semi-structured interviews, the number of medicinal plant species recognized by the young Papuans (35 species) was higher than that of the young Moluccans (30 species) (Table 1). There were nevertheless 13 medicinal plant species that recognized by both ethnicities namely cogon grass, liniment tree, ginger, common guava, lime, spadeleaf, drumstick tree, turmeric, Indian mulberry, roselle, bitterweed, citronella grass, and better pepper.

Of all medicinal plant species recognized by both ethnicities, 13 species, i.e. garlic, bitterweed, common fig, lime, true aloe, shoeblackplant, turmeric, Indian mulberry, stonebreaker, neem, mulberry, spadeleaf, and ant plant are plant species that have been shown to boost immunity. Many studies show that these plant species are well known to have anti-inflammatory, antioxidant, immunomodulatory, and antiviral.

Based on the results of the focus group discussion conducted in the third stage namely participation by consultation, the assisted communities were known to have a better understanding of medicinal plant species and traditional herbal medicines. In addition, the assisted communities also understood the importance of digitizing local knowledge on medicinal plant species and traditional herbal medicines. Furthermore, in the focus group discussion forum, some members of the assisted communities (40 young Papuans and Moluccans) expressed their opinion to the external professionals to make herbal drinks based on the knowledge they gained in the second stage of this activity (participation in information giving) and also discussed the ingredients and manufacturing methods. They wanted to combine plant parts used for medicinal ingredients from several medicinal plant species.

In the fourth stage namely functional participation, 40 young Papuans and Moluccans formed 8 groups. The formation of these groups did not involve external professionals. The eight groups of assisted community members made herbal drinks with recipes and manufacturing methods according to the creativity of each group (Figure 2; Table 2). The eight herbal drinks products named Jamu Mioko, Herbal Tim, Tealang, Tealang Plus, Dj Fresh, Kunyit Asam, Jahe Kencur, dan Berat Kencur.

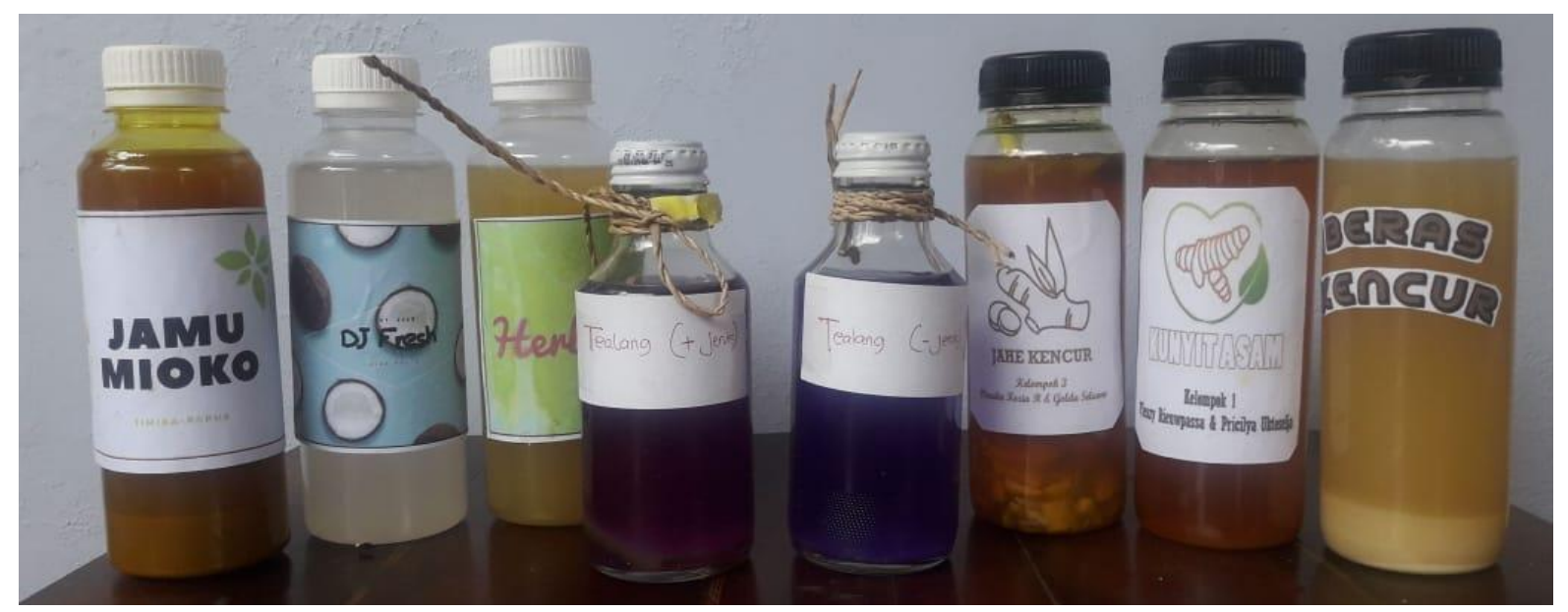

Figure 2. Traditional herbal drink products from assisted communities. 
Tabel 2. Ingredients and how to make herbal drinks

\begin{tabular}{lll}
\hline Herbal Drink Name & Komposition & Manufacturing Methods \\
\hline Jamu Mioko & $\begin{array}{l}\text { Turmeric, aromatic ginger, } \\
\text { tamarind, betel leaf, brown } \\
\text { sugar, salt, water }\end{array}$ & Boiled \\
Herbal Tim & $\begin{array}{l}\text { Cucumber, lime, mint leaf, } \\
\text { brown sugar, granulated sugar, } \\
\text { water }\end{array}$ & Make juice by blending \\
& $\begin{array}{l}\text { Butterfly pea, citronella grass, } \\
\text { pandan leaf, granulated sugar, }\end{array}$ & Boiled \\
Tealang & $\begin{array}{l}\text { water } \\
\text { Butterfly pea, citronella grass, } \\
\text { pandan leaf, lime, granulated } \\
\text { Tealang Plus }\end{array}$ & Boiled \\
& $\begin{array}{l}\text { Sugar, water } \\
\text { Young coconut, citronella grass } \\
\text { Dj Fresh }\end{array}$ & Roasted \\
Kunyit Asam & $\begin{array}{l}\text { brown sugar, water } \\
\text { Ginger, aromatic ginger, }\end{array}$ & \\
Jahe Kencur & $\begin{array}{l}\text { turmeric, citronella grass, } \\
\text { tamarind, lime, brown sugar, } \\
\text { water }\end{array}$ & \\
& $\begin{array}{l}\text { Rice, aromatic ginger, ginger, } \\
\text { cinnamon, pandan leaf, lime, } \\
\text { granulated sugar, salt, water }\end{array}$ & \\
& Boiled \\
Beras Kencur & &
\end{tabular}

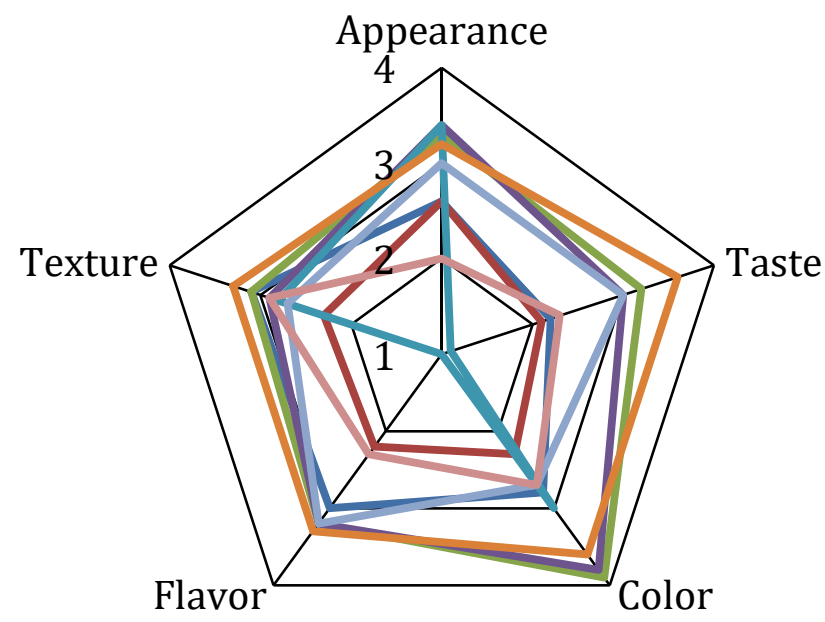

-Jamu Mioko

Herbal Tim

-Tealang

Tealang Plus

-Dj Fresh

Kunyit Asam

Jahe Kencur

Beras Kencur

Figure 3. The results of organoleptic test on herbal drink products $(n=10)$. Notes: $1-$ dislike/unattractive, 2 - less like/less attractive, 3 - like/attractive, 4 - very like/very attractive 
The results of organoleptic test on appearance, taste, color, flavor, and texture of the eight herbal drink products (Figure 3) showed that the Kunyit Asam was the most preferred by consumers, although it was considered less innovative by consumers. Tealang was the second herbal drink that was preferred and considered very innovative by consumers.

The reflection was carried out to measure the social changes in the assisted communities about the importance of using medicinal plants to strengthen immunity and avoid complications of COVID-19 infection. According to the result, it showed that majority (>81\%) of young Papuans and Moluccans knew the medicinal plant species and plant parts that could be used for sthrengthening immunity. Majority of the assisted community members $(>70 \%)$ even stated that they would plant or cultivate medicinal plants in their homes because $71-81 \%$ of them agreed that medicinal plants were useful for increasing immunity and 66-77\% of them agreed that traditional medicines were safe.

\section{Discussion}

Herbal medicine hasbeen reported worldwide as an essential component of the cultural heritage of a group or society. ${ }^{22}$ In the rural areas of developing countries, where medicinal plants are often the only available and affordable treatment, the use of herbal preparations plays a crucial role in the livelihoods of people. ${ }^{23}$ Participatory learning and action approach was used for empowering young Papuans and Moluccans in utilizing medicinal plants. Although based on the level of community involvement, participation has been categorized into seven stages, ${ }^{24}$ this community service activity used only four stages ranging from 'bad' form of participation, i.e. passive participation to 'better' forms of participation, such as participation by consultation and functional participation. Functional participation was chosen because it captures the form of participation that is most often associated with efficiency arguments: people participate to meet project objectives more effectively. ${ }^{25}$ This participation is also the most frequently found type of participation in development. ${ }^{26}$ The last two participation stages namely interactive participation and self-mobilization were not used in this community service activity due to time and space limitation.

Passive participation is the most inadequate of the seven stages of participation because it is a unilateral announcement by an administration or project management without listening to people's responses. However, through this participation stage this community service activity receieved good responses from the assisted communities

\footnotetext{
${ }^{22}$ Bruschi, Piero, Mara Sugni, Arianna Moretti, Maria Adele Signorini, and Gelsomina Fico. “Children's Versus Adult's Knowledge of Medicinal Plants: An Ethnobotanical Study in Tremezzina (Como, Lombardy, Italy)." Revista Brasileira de Farmacognosia 29, no. 5 (September-October 2019): 644-655.

${ }^{23}$ WHO. "Traditional Medicine - Growing Needs and Potential." Policy Perspective on Medicines 2 (May, 2002): 1-6.

${ }^{24}$ Pretty, Jules N, Irene Guijt, Ian Scoones, and John Thompson. Participatory Learning \& Action: A Trainer's Guide. London: International Institute for Environment and Development, 1995.

${ }^{25}$ Cornwall, Andrea. "Unpacking 'Participation': Models, Meanings and Practices." Community Development Journal 43, no. 3 (July, 2008): 269-283.

${ }^{26}$ Rudqvist, Anders and Prudence Woodford-Berger. Evaluation and Participation: Some Lessons. Sida, Stockholm: Department for Evaluation and Internal Audit, DAC Expert Group on Aid Evaluation, 1996.
} 
which was marked by the large number (163 people) of young Papuans and Moluccans wanted to take part in this activity. However, because passive participation does not even extend as far as consultation or making an input to decisions, the information is even often inaacurate, ${ }^{27}$ empowerement require a high level of community participation practice that promotes active involvement of the assisted communities.

Based on the results of the second stage of participation namely participation in information giving, the assisted communities are known to have knowledge of various medicinal plants. The results of the interview also showed that their knowledge of medicinal plants is closely related to the knowledge obtained from family and also related to the resources that grow in their areas (especially gardens/ yards and forests). Other studies also showed the same results. ${ }^{28}$ However, there are significant differences in the number of medicinal plant species that are known by you Papuans and Moluccans. Young Papuans knew and used a greater number of medicinal plant species, although fewer members of the assisted communities were interviewed compared to the Moluccans. Although local ecologies are important in affecting how people interact with their biological surroundings, the selection of medicines is neither merely a reflection of epidemiological patterns ${ }^{29}$ nor simply a function of the diversity and availability of ambient flora and fauna. ${ }^{30}$ Moreover, it is hypothesized that other factors explaining this knowledge acquisition such as direct observation of the surrounding environment, contact with peers, school programs or personal interest in medicinal plants. ${ }^{31}$

The highest stages of involvement of the assisted communities in this activity are participation by consultation and functional participation. In accordance with the description, in participation by consultation the external professionals listened to the wishes of the assisted community to make herbal drinks and helped them providing solutions. Furthermore, the assisted communities participated by forming groups to fulfill the predetermined goals related to this activity. In this last stage of participation (functional participation), young Papuans and Moluccans groups were able to make various herbal drinks which are expected to increase immunity. Based on the appearance, taste, color, flavor, and texture of herbal drink products, Kunyit Asam which contained turmeric and ginger, and Tealang which contained butterfly pea flower and citronella grass are the most preferred by consumers. The main ingredients in these two types of herbal drinks are known to have functions such as increasing immunity, antioxidant, anti-

\footnotetext{
${ }^{27}$ Kilroy, Walt. "From Conflict to Ownership: Participatory Approaches to the Re-integration of ExCombatants in Sierra Leone." Irish Studies in International Affairs 22, no. 1 (Januari, 2011): 127-144.

${ }^{28}$ Dopico, Eduardo, Jose L. San Fabian, and Eva Garcia-Vazquez. "Traditional Medicine in Twenty-First Spain." Human Ecology 36, no. 125-129 (November 20, 2007):125-129; Lozada, Mariana, Ana Ladio, and Mariana Weigandt. "Cultural Transmission of Ethnobotanical Knowledge in a Rural Community of Northwestern Patagonia, Argentina." Economic Botany 60, no. 4 (December, 2006): 374-385.

${ }^{29}$ Gollin, Lisa X. "Subtle and Profound Sensory Attributes of Medicinal Plants Among the Kenyah Leppo' Ke of East Kalimantan, Borneo." Journal of Ethnobiology 24, no. 2 (Fall/Winter 2004): 173-201.

${ }^{30}$ Leonti, Marco, Otto Sticher, Michael Heinrich. "Medicinal Plants of the Popoluca, México: Organoleptic Properties as Indigenous Selection Criteria." Journal of Ethnopharmacology 81, no. 3 (August 1, 2002): 307-315.

${ }^{31}$ Bruschi, Piero, Mara Sugni, Arianna Moretti, Maria Adele Signorini, Gelsomina Fico. “ Children's Versus Adult's Knowledge of Medicinal Plants: An Ethnobotanical Study in Tremezzina (Como, Lombardy, Italy)." Revista Brasileira de Farmacognosia 29, no. 5 (September-October 2019): 644-655.
} 
inflammatory, and antiviral. ${ }^{32}$

Local knowledge of young Papuans and Moluccans about medicinal plant species plays a role not only in providing immune maintenance for local population but also has the potential to be shared outside the regions of the two ethnic groups. Therefore, empowering the assisted communities to understand and be motivated to preserve and develop medicinal plants to maintain immunity during the COVID-19 pandemic is very necessary. In addition, assistance to improve the skills of assisted communities in menufacturing medicinal plants that can boost immunity is also needed. Participatory learning and action approach can be used to empower the assisted communities, although several obstacles need to be considered, such as doubt and fear, lack of information, lack of understanding of the importance of participation, and environmental factors.

\section{Conclusion}

Even though research on medicinal plants has receive a lot of attention, collecting data and information on the use of traditional medicinal plants and how this knowledge about medicinal plants disseminated among society members is very important. Participatory learning and action approach can be used for empowering the community although several obstacles such as doubt and fear, lack of information, lack of understanding of the importance of participation, and environmental factors need to be considered.

After participating in this community service activity, the assisted communities showed that they have experienced a variety of social changes regarding the importance of using medicinal plants to maintain immunity and avoid complications of COVID-19 infection. For example, the majority of assisted community members become more understood about medicinal plant species and traditional herbal medicine and the need to digitize this knowledge. They also stated that they would plant or cultivate medicinal plants in their homes, agreed that medicinal plants were useful for strengthening immunity, and suggested that traditional medicine was safe.

\footnotetext{
${ }^{32}$ Afrianto, Whisnu Febry, Fadila Tamnge, and Laeli Nur Hasanah. "A Relation Between Ethnobotany and Bioprospecting of Edible Flower Butterfly Pea (Clitoria ternatea) in Indonesia." Asian Journal of Ethnobiology 3, no. 2 (November, 2020): 51-61; Imo, Chinedu, and Jivini Salvation Za'aku. "Medicinal Properties of Ginger and Garlic: A Review." Current Trends in Biomedical Engineering and Biosciences 18, no. 2(Febryary, 2019): 47-52; Mashhadi, Nafiseh Shokri, Reza Ghiasvand, Gholamreza Askari, Mitra Hariri, Leila Darvishi, and Mohammad Reza Mofid."Anti-Oxidative and Anti-Inflammatory Effects of Gingers in Health and Physical Activity: Review of Current Evidence." International Journal of Preventive Medicine 4, no. Suppl 1 (April, 2013): S36-S42; Panyod, Suraphan, Chi-Tang Ho, and Lee-Yan Sheen. "Dietary Therapy and Herbal Medicine for COVID-19 Prevention: A Review and Perspective." Journal of Traditional and Complementary Medicine 10, no. 4 (July, 2020): 420-427.
} 


\section{Acknowledgement}

The authors would like to thank students at the Satya Wacana Christian University who participated in this community service activity.

\section{References}

Afrianto, Whisnu Febry, Fadila Tamnge, and Laeli Nur Hasanah. "A Relation Between Ethnobotany and Bioprospecting of Edible Flower Butterfly Pea (Clitoria ternatea) in Indonesia." Asian Journal of Ethnobiology 3, no. 2(November, 2020): 51-61

Babich, Olga, Stanislav Sukhikh, Alexander Prosekov, Lyudmila Asyakina, and Svetlana Ivanova. "Medicinal Plants to Strengthen Immunity during a Pandemic." Pharmaceuticals 13, no. 10 (October 15, 2020): 313.

Batiha, Gaber El-Saber, Luay M. Alkazmi, Lamiaa G. Wasef, Amany Magdy Beshbishy, Eman H. Nadwa, and Eman K. Rashwan. "Syzygium aromaticum L. (Myrtaceae): Traditional Uses, Bioactive Chemical Constituents, Pharmacological and Toxicological Activities." Biomolecules 10, no. 2 (February, 2020): 202.

Bruschi, Piero, Mara Sugni, Arianna Moretti, Maria Adele Signorini, Gelsomina Fico. “Children's Versus Adult's Knowledge of Medicinal Plants: An Ethnobotanical Study in Tremezzina (Como, Lombardy, Italy)." Revista Brasileira de Farmacognosia 29, no. 5 (September-October 2019): 644-655.

Budiarti, Merry, Anshary Maruzy, Rohmat Mujahid, Aniska Novita Sari, Wahyo Jokopriyambodo, Tri Widayat, and Slamet Wahyono. "The use of antimalarial plants as traditional treatment in Papua Island, Indonesia." Heliyon 6, no. 12 (December, 2020): e05562.

Cornwall, Andrea. "Unpacking 'Participation': Models, Meanings and Practices." Community Development Journal 43, no. 3 (July, 2008): 269-283.

Cotton, Catherine M. Ethnobotany: Principles and Applications. Chichester, England: John Wiley, 1996.

Dopico, Eduardo, Jose L. San Fabian, and Eva Garcia-Vazquez. "Traditional Medicine in Twenty-First Spain." Human Ecology 36, no. 125-129 (November 20, 2007):125-129.

Elfahmi, Herman J. Woerdenbag, and Oliver Kayser. "Jamu: Indonesian Traditional Herbal Medicine Towards Rational Phytopharmacological Use." Journal of Herbal Medicine 4, no. 2 (June, 2014): 51-73.

Gollin, Lisa X. "Subtle and Profound Sensory Attributes of Medicinal Plants Among the Kenyah Leppo' Ke of East Kalimantan, Borneo." Journal of Ethnobiology 24, no. 2 (Fall/Winter 2004): 173-201. 
Han, Emeline, Melisa Mei Jin Tan, Eva Turk, Devi Sridhar, Gabriel M Leung, Kenji Shibuya, Nima Asgari, Juhwan Oh, Alberto L. García-Basteiro, Johanna Hanefeld, et al. "Lessons Learnt from Easing COVID-19 Restrictions: An Analysis of Countries and Regions in Asia Pacific and Europe." The Lancet 396, no. 10261 (November 7-13, 2020): 1525-1534.

Imo, Chinedu, and Jivini Salvation Za'aku. "Medicinal Properties of Ginger and Garlic: A Review." Current Trends in Biomedical Engineering and Biosciences 18, no. 2(Febryary, 2019): 47-52

Kilroy, Walt. "From Conflict to Ownership: Participatory Approaches to the Reintegration of Ex-Combatants in Sierra Leone." Irish Studies in International Affairs 22, no. 1 (Januari, 2011): 127-144.

Kumrungsee, Thanutchaporn, Peipei Zhang, Maesaya Chartkul, Noriyuki Yanaka, and Norihisa Kato. "Potential Role of Vitamin B6 in Ameliorating the Severity of COVID19 and Its Complications." Frontiers in Nutrition 7, (October 29, 2020): 562051.

Lense, Obed. "The wild plants use as traditional medicines by indigenous people of Manokwari, West Papua." Biodiversitas 13, no. 2 (April, 2012: 98-106.

Leonti, Marco, Otto Sticher, Michael Heinrich. "Medicinal Plants of the Popoluca, México: Organoleptic Properties as Indigenous Selection Criteria." Journal of Ethnopharmacology 81, no. 3 (August 1, 2002): 307-315.

Lipsitch, Marc, Yonatan H. Grad, Allesandro Sette, and Shane Crotty. "Cross-Reactive Memory T Cells and Herd Immunity to SARS-CoV-2." Nature Reviews Immunology 20 (October 6, 2020): 709-713.

Long, Quan-Xin, Xiao-Jun Tang, Qiu-Lin Shi, Hai-Jun Deng, Jun Yuan, Jie-Li Hu, Wei Xu, Yong Zhang, Fa-Jin Lv, Kun Su, et al. "Clinical and Immunological Assessment of Asymptomatic SARS-CoV-2 Infections" Nature Medicine 26, no. 8 (June 18, 2020): 1200-1204.

Lozada, Mariana, Ana Ladio, and Mariana Weigandt. "Cultural Transmission of Ethnobotanical Knowledge in a Rural Community of Northwestern Patagonia, Argentina." Economic Botany 60, no. 4 (December, 2006): 374-385.

Marchall, Michael. "The Lasting Misery of Coronavirus Long-Haulers" Nature 585, (September 14, 2020): 339-341.

Mashhadi, Nafiseh Shokri, Reza Ghiasvand, Gholamreza Askari, Mitra Hariri, Leila Darvishi, and Mohammad Reza Mofid."Anti-Oxidative and Anti-Inflammatory Effects of Gingers in Health and Physical Activity: Review of Current Evidence." International Journal of Preventive Medicine 4, no. Suppl 1 (April, 2013): S36-S42.

Merad, Miriam, and Jerome C. Martin. "Pathological Inflammation in Patients with COVID- 
19: A Key Role for Monocytes and Macrophages." Nature Reviews Immunology 20, (May 6, 2020): 355-362.

Morens, David M, and Anthony S. Fauci. "Emerging Pandemic Diseases: How We Got to COVID-19." Cell 182, no. 5, (September 3, 2020): 1077-1092.

Mukhtar, Muhammad, Mohammad Arshad, Mahmood Ahmad, Roger J. Pemerantz, Brian Wigdahl, and Zahida Parveen. "Antiviral Potentials of Medicinal Plants." Virus Research 131, no. 2 (February, 2008): 111-120.

Panyod, Suraphan, Chi-Tang Ho, and Lee-Yan Sheen. "Dietary Therapy and Herbal Medicine for COVID-19 Prevention: A Review and Perspective." Journal of Traditional and Complementary Medicine 10, no. 4 (July, 2020): 420-427.

Pretty, Jules N, Irene Guijt, Ian Scoones, and John Thompson. Participatory Learning \& Action: A Trainer's Guide. London: International Institute for Environment and Development, 1995.

Rudqvist, Anders and Prudence Woodford-Berger. Evaluation and Participation: Some Lessons. Sida, Stockholm: Department for Evaluation and Internal Audit, DAC Expert Group on Aid Evaluation, 1996.

Schultze, Joachim, and Anna C. Aschenbrenner. "COVID-19 and The Human Innate Immune System.” Cell 184, no 7. (April 1, 2021): 1671-1692.

Susiarti, Siti, Mulyati Rahayu, dan Mohammad Fathi Royyani. "Pengetahuan dan Pemanfaatan Tumbuhan Obat Masyarakat Tobelo Dalam di Maluku Utara." Media Litbangkes 25, no 4(Desember, 2015): 211-218.

Wang, Chen, Peter W. Horby, Frederick G. Hayden, and George F. Gao. "A Novel Coronavirus Outbreak of Global Health Concern." Lancet 395, no. 10223 (February 15,2020 ): 470-473.

Vabret, Nicolas, Graham J. Britton, Conor Gruber, Samarth Hegde, Joel Kim, Maria Kuksin, Rachel Levantovsky, Louise Malle, Alvaro Moreira, Matthew D. Park, et al. "Immunology of COVID-19: Current State of the Science." Immunity 52, no. 6 (June 16, 2020): 910-941.

Widiyastuti, Yuli, dan Tri Widayat. "Inventarisasi Tanaman Obat di Kabupaten Jayapura Propinsi Papua." Jurnal Tumbuhan Obat Indonesia 6, no. 2 (Desember, 2013): 116-126.

World Health Organization. "Coronavirus disease (COVID-19) Advice for the Public." https://www.who.int/emergencies/diseases/novel-coronavirus-2019/advicefor-public. Diakses 22 Juni 2021.

World Health Organization. "Indonesia: WHO Coronavirus Disease (COVID-19) 
Dashboard." https://covid19.who.int/region/searo/country/id. Diakses 22 Juni 2021.

Zhang, Deng-Hai, Kun-Lun Wu, Xue Zhang, Sheng-Qiong Deng, and Bin Peng. "In Silico Screening of Chinese Herbal Medicines with the Potential to Directly Inhibit 2019 Novel Coronavirus." Journal of Integrative Medicine 18, no. 2 (March, 2020): 152-158.

Zhang, Lei, and Yunhui Liu. "Potential Interventions for Novel Coronavirus in China: A Systematic Review." Journal of Medical Virology 92, no. 5 (February 13, 2020): 479-490. 